\title{
COUPLING OF MULTIPLE OPIOID RECEPTORS TO GTPaSe FOLLOWING SELECTIVE RECEPTOR ALKYLATION IN BRAIN MEMBRANES
}

\author{
Mary J. Clark and F. Medzihradsky \\ Departments of Biological Chemistry and Pharmacology, The University of Michigan Medical School, \\ Ann Arbor, Michigan 48109, U.S.A.
}

(Accepted 20 May 1987)

\begin{abstract}
Summary-Opioid agonists of the mu, kappa and delta types stimulated low- $K \mathrm{~m}$ guanosine triphosphatase (GTPase) in membranes, from the brain of the rat by up to $34 \%$, with potencies the rank order of which corresponded to the respective binding affinities to opioid receptor. In general, kappa ligands stimulated GTPase to a lesser degree than mu or delta opiates. The coupling of a given type of opioid receptor to GTPase was resolved by direct or protective alkylation of the other receptors. Treatment of the membranes with $\beta$-funaltrexamine abolished the stimulation of GTPase by sufentanil and levorphanol (mu), but not by bremazocine (kappa) or DSLET (delta). On the other hand, prior incubation with Superfit, an alkylating agent with selectivity for the delta opioid receptor, specifically eliminated the effect of DSLET. Partial alkylation by increasing concentrations of Superfit gradually reduced the extent of stimulation of GTPase by DSLET. The successive treatment of membranes with Superfit and $\beta$-funaltrexamine blocked the actions of DSLET, sufentanil and levorphanol, but had no effect on the stimulation of the GTPase by bremazocine. Selective coupling of an opioid receptor to GTPase was also obtained after incubation of membranes with $\beta$-chlornaltrexamine in the presence of protective concentrations of $\mathrm{mu}$, kappa or delta opioid ligands. Alkylation resolved the coupling of the non-selective opiate etorphine: the sum of stimulation of GTPase in the receptor-selective membranes equalled maximal stimulation of enzyme in untreated membranes. Naloxone blocked the stimulation of GTPase by mu, kappa or delta agonists, but ICI-174,864 specifically inhibited the effect of DSLET. The results describe the use of receptor-selective membranes from brain to characterize the coupling of multiple opioid receptors to high-affinity GTPase, the inhibitory binding protein for GTP of the adenylate cyclase complex.
\end{abstract}

Key words: multiple opioid receptors, opioid receptor-effector coupling, GTP binding proteins, receptor alkylation, brain membranes, rat brain.

The binding of agonists to opioid receptors appears to be translated into at least two different, although not necessarily independent, alterations in cell function: an inhibition of the neuronal action potential discharge (Bixby and Spitzer, 1983; Williams and North, 1984) and the inhibition of adenylate cyclase. The interaction of opiates with adenylate cyclase has been described in NG108-15 neuroblastoma $\times$ glioma hybrids (Sharma, Nirenberg and Klee, 1975), slices of brain (Barchfeld, Maassen and Medzihradsky, 1982) and membranes from brain (Law, Wu, Koehler and Loh, 1981). In addition to causing inhibition of adenylate cyclase, opiates stimulated the activity of a low- $K \mathrm{~m}$ guanosine triphosphatase (GTPase) in membranes from NG108-15 cells (Koski and Klee, 1981) and rat brain (Barchfeld and Medzihradsky, 1984). In NG108-15 hybrid cells pertussis toxin inhibited the stimulation of GTPase by opiates, thus suggesting the involvement of the binding protein for GTP (Hildebrandt, Sekura, Codina, Iyenger, Manclark and Birnbaumer, 1983) in the coupling of opioid receptors to adenylate cyclase
(Burns, Hewlett, Moss and Vaughan, 1983; Kurose, Katada, Amaro and Ui, 1983). Considering the requircment of the latter process for GTP (Blume, Lichtshtein and Boone, 1979), the opiate-sensitive GTPase is causally linked to the mechanism of opioid receptor-effector interaction: the hydrolysis of GTP uncouples the receptor-effector complex. The opioid receptor mediated stimulation of low- $K \mathrm{~m}$ GTPase in membranes from brain has been described (Barchfeld and Medzihradsky, 1984). The general characteristics by which opiates stimulated GTPase corresponded to those of their inhibition of adenylate cyclase in cellular preparations from the brain of the rat (Barchfeld et al., 1982). Recently, differences in the degree and potency by which ligands of the multiple opioid receptors stimulated GTPase in brain were reported (Clark and Medzihradsky, 1985; Clark, Levenson and Medzihradsky, 1986). In the present work, the stimulation of GTPase by mu, kappa and delta opiates in membranes from brain, alkylated to provide specificity toward a given type of opioid receptor, has been resolved and characterised. 


\section{METHODS}

\section{Materials}

Most of the opiates, including $\beta$-FNA $(\beta$-funaltrexamine) and Superfit (cis-( \pm$)-3$ methylfentanylisothiocyanate) (Clark et al., 1986; Smith, Jacobson, Burke, Rice and Woods, 1985), used in this study were obtained through the Narcotic Drug and Opioid Peptide Basic Research Center, The University of Michigan. UM 1071R ([IR,5R,9R, $\left.2^{\prime \prime} \mathrm{R}\right]$-5,9-dimethyl-2'-hydroxy-2-tetrahydrofurfuryl6,7-benzomorphan is a benzomorphan derivative with kappa agonist activity (Medzihradsky, Dahlstrom, Woods, Fischel and Mitsos, 1984). ICI 171,864 ( $N, N$-diallyl-Tyr-Aib-Aib-Phe-Leu-OH; Aib: $d$-aminoisobutyric acid) is a highly selective antagonist at the delta opioid receptor (Cotton, Giles, Miller, Shaw and Timms, 1984); $\beta$-CNA $(\beta$-chlornaltrexamine) was purchased from Research Biochemicals Inc., Wayland, Massachusetts, U.S.A. and DSLET ([D-Ser $\left.{ }^{2}, \mathrm{le}^{5}\right]$ enkephalin- $\left.\mathrm{Thr}^{6}\right)$ was obtained from Cambridgc Rescarch Biochemicals Ltd, Atlantic Beach, New York, U.S.A. Gamma- $\left[{ }^{32}\right.$ P]GTP (20 Ci/mmol) was obtained from Amersham Corporation, Arlington Heights, Illinois, U.S.A. The biochemicals used in the assay for GTPase, including the stable adenosine and guanosine derivatives $\operatorname{App}(\mathrm{NH}) \mathrm{p} \quad(\beta, \gamma$-imidoadenosine-5'-triphosphate $)$ and $\operatorname{Gpp}(\mathrm{NH}) \mathrm{p} \quad(\beta, \gamma$-imidoguanosine-5'-triphosphate), were from Sigma Chemical Co., St Louis, Missouri, U.S.A.

\section{Isolation of membranes}

Parts of this procedure have been published previously (Fischel and Medzihradsky, 1981). Male, Sprague-Dawley rats weighing $200 \mathrm{~g}$ were decapitated and the brains excised at $4^{\circ} \mathrm{C}$. The cerebrum was dissected, washed in Tris- $\mathrm{HCl}(\mathrm{pH} 7.4)$, blotted and cleaned of adhering blood vessels. The weighed tissue was disrupted for $60 \mathrm{sec}$ in $100 \mathrm{vol}$ of ice-cold $50 \mathrm{mM}$ Tris- $\mathrm{HCl}$ (pH 7.4), using a Polytron homogenizer (Model PT10, Brinkman Instruments Inc., Westbury, New York) at the power output 6.5. The homogenate was centrifuged at $20,000 \times g$ for $15 \mathrm{~min}$ in the cold. The pellet obtained was suspended with the original amount of buffer, using a Dounce allglass homogenizer. Aliquots of this suspension, sufficient for experiments on one given day, were frozen at $-70^{\circ} \mathrm{C}$. Prior to use, the suspension was quickly thawed in a water bath and briefly dispersed in a Dounce homogenizer. The concentration of protein in the latter preparation was approximately $0.5 \mathrm{mg} / \mathrm{ml}$.

\section{Receptor alkylation}

For the direct alkylation, the suspension of cerebral membranes in Tris- $\mathrm{HCl}(\mathrm{pH} 7.4)$, with a concentration of protein of $0.35 \mathrm{mg} / \mathrm{ml}$, was incubated with $100 \mu \mathrm{M}$ Superfit for $40 \mathrm{~min}$ at $25^{\circ} \mathrm{C}$ in a shaking water bath. After centrifugation at $20,000 \times g$ for
$15 \mathrm{~min}$ at $2^{\circ} \mathrm{C}$, the pellet was suspended in a Dounce homogenizer with the original volume of $50 \mathrm{mM}$ Tris- $\mathrm{HCl}$ ( $\mathrm{pH} 7.4)$. This suspension was then incubated with $200 \mu \mathrm{M} \beta$-funaltrexamine for $40 \mathrm{~min}$ at $25^{\circ} \mathrm{C}$ in a shaking water bath. After a five-fold dilution with $\mathrm{Tris}-\mathrm{HCl}(\mathrm{pH} 7.4)$, the suspension was centrifuged at $20,000 \times \mathrm{g}$ for $15 \mathrm{~min}$ at $4{ }^{\circ} \mathrm{C}$. The pellet was suspended in 5 original volumes of the Tris buffer and centrifuged as described above. The washing procedure was repeated once more and the pellet suspended in the original volume of Tris- $\mathrm{HCl}$ (pH 7.4). The alkylated membranes were either used fresh or frozen in aliquots at $-70^{\circ} \mathrm{C}$. Freezing and storage had no detectable effects on the results.

For the protective alkylation, the suspension of cerebral membranes in Tris- $\mathrm{HCl}$ buffer ( $\mathrm{pH} 7.4$ ), with a protein concentration of $0.35 \mathrm{mg} / \mathrm{ml}$, was incubated with $800 \mu \mathrm{M}$ levorphanol or bremazocine, or $400 \mu \mathrm{M}$ DSLET for $5 \mathrm{~min}$ at $25^{\circ} \mathrm{C}$. After $\mathrm{NaCl}$ and $\beta$-chlornaltrexamine were added to a final concentration of $100 \mathrm{mM}$ and $25 \mu \mathrm{M}$, respectively, the suspension was incubated for $40 \mathrm{~min}$ at $25^{\circ} \mathrm{C}$, and then centrifuged at $20,000 \times \mathrm{g}$ for $15 \mathrm{~min}$ at $2^{\circ} \mathrm{C}$. The pellet was suspended in a Dounce homogenizer with 5 original volumes of the Tris buffer, and again centrifuged as described above. The washing procedure was repeated once more, and the final pellet was suspended in the original volume of Tris buffer. An additional washing step had no effect on the parameters of stimulation of GTPase. Aliquots of the membrane suspension were frozen at $-70^{\circ} \mathrm{C}$.

\section{Assay of GTPase}

The assay represented a modification of the previously published procedure (Barchfeld and Medzihradsky, 1984) and was based on the method of Cassel and Selinger (1976). In a final volume of $100 \mu \mathrm{l}$ the assay medium (in $4 \mathrm{ml}$ polypropylene tubes) contained: $0.5 \mu \mathrm{M}\left[{ }^{32} \mathrm{P}\right] \mathrm{GTP}(0.05-0.1 \mu \mathrm{C}$ per tube), 2-4 $\mu \mathrm{g}$ membrane protein, $12.5 \mathrm{mM}$ Tris- $\mathrm{HCl}$ (pH 7.5), $120 \mathrm{mM} \mathrm{NaCl}, 5 \mathrm{mM} \mathrm{MgCl} 2,0.1 \mathrm{mM}$ ethylene diamine tetra ammonium (EDTA), $2 \mathrm{mM}$ dithiothreitol, $1 \mathrm{mM}$ App(NH)p, $1 \mathrm{mM}$ ouabain, $0.5 \mathrm{mM}$ adenosine triphosphate (ATP), $10 \mathrm{mM}$ creatine phosphate and 5 units creatine kinase. In experiments with dynorphin, the tubes were initially rinsed with $1 \%$ bovine serum albumin in $50 \mathrm{mM}$ Tris $\mathrm{HCl}(\mathrm{pH} \mathrm{7.4)}$. The opioid ligands were added in $10-20 \mu 1$ of aqueous solutions. In separate tubes, the reaction mixture also contained $50 \mu \mathrm{M}$ GTP to measure the activity of the opiate-insensitive, high- $K \mathrm{~m}$ GTPase. The cpm's obtained in the presence of $50 \mu \mathrm{M}$ GTP were subtracted from the cpm's for total enzyme activity to yield a cpm value representing the activity of the opiate-sensitive, low-Km GTPase.

After the addition of radiolabelled GTP, the samples were incubated for $10 \mathrm{~min}$ at $37^{\circ} \mathrm{C}$ and $1 \mathrm{ml}$ of $25 \%$ activated charcoal (suspended at $\mathrm{pH} 2.3$ in phosphoric acid) was added. After standing for $30 \mathrm{~min}$ in ice, the tubes were centrifuged at $5000 \times \mathrm{g}$ 
for $15 \mathrm{~min}$ and $300 \mu \mathrm{l}$ of the supernatant was subjected to liquid scintillation counting. The following controls were routinely included in each assay: basal activity of GTPase in the absence of opiates, hydrolysis of GTP in the absence of membranes and hydrolysis of GTP prior to sample incubation.

\section{Determination of protein}

The method of Lowry, Rosebrough, Farr and Randall (1951) was used with bovine serum albumin as standard.

\section{Statistical evaluation of the data}

The stimulation of low- $K \mathrm{~m}$ GTPase in brain was characterized by the parameters $K_{\mathrm{S}}$ and $S_{\max }$. The $K_{5}$, the ligand concentration producing half-maximal stimulation of basal enzyme activity, was determined by linear regression from plots relating stimulation of GTPase in probits to the log of ligand concentration at 4-5 data points. The $S_{\max }$, the maximal stimulation of basal low- $K \mathrm{~m}$ GTPase, was obtained with gradually increasing concentrations of ligand as a well-defined upper limit of enzyme activity. Opioid agonists, present at concentrations greater than that yielding $S_{\max }$, progressively inhibited stimulation of GTPase. The potency of antagonists in inhibiting the stimulation of GTPase was expressed as $\mathrm{EC}_{\varsigma_{0}}$ and was determined from log-probit plots, as described above. The values for $K_{\mathrm{s}}, S_{\max }$ and $\mathrm{EC}_{50}$ were expressed as means \pm standard deviations, based upon 3-6 experiments. The significance of the data was tested by a one-way analysis of variance that compared effects of ligands with control, or for a given ligand, alkylated membranes with no treat- ment. The results were accepted as different from control if the computed statistic exceeded the corresponding theoretical statistic at the 5\% level of significance. The comparison of the means was carried out by the Scheffe test (Scheffe, 1953).

\section{RESULTS}

The rationale for the composition of the GTPase assay medium is described in the original publication by Cassel and Selinger (1976). The present authors have confirmed $0.5 \mu \mathrm{M}$ and $50 \mu \mathrm{MGTP}$, described by Koski and Klee (1981), as the optimal concentrations to measure the opiate-sensitive and -insensitive activities of GTPase, respectively. Procedural details of the method described (Koski and Klee, 1981) were modified in order to improve precision, an important aspect considering the limited range of stimulation of the enzyme (Fig. 1). Initially, the linearity of the enzyme assay with time and protein was established. In addition, it was shown that the basal rate of activity of GTPase in mcmbranes of brain was not altered by the alkylations with $\beta$-funaltrexamine and Superfit. The variability of the basal activity of GTPase (Table 1) reflected the contribution of several preparations of membranes used in this study. Compared to mu opiates, stimulation of low- $K \mathrm{~m}$ GTPase by kappa ligands was considerably less (Fig. 1). The delta opiate DSLET stimulated GTPase to an extent similar to, or greater than that of mu ligands (Fig. 3). The rank order of the $K_{\mathrm{S}}$ values for stimulation of the enzyme (Fig. 1), correlated with the receptor binding affinities of the respective opiates (Medzihradsky et al., 1984).

Table 1. Stimulation of GTPase in alkylated membranes

\begin{tabular}{|c|c|c|c|c|c|c|c|}
\hline \multirow[t]{2}{*}{ Experimental conditions } & $\begin{array}{c}\text { Basal GTPase } \\
\text { activity } \\
\left(\frac{\text { pmol } P_{\mathrm{i}}}{\text { mg protein min }}\right)\end{array}$ & $\begin{array}{c}K_{\mathrm{S}} \\
(\mu \mathrm{M})\end{array}$ & $\begin{array}{l}S_{\max } \\
(\%) \\
\end{array}$ & \multicolumn{3}{|c|}{ Stimulation of GTPase activity } & $\begin{array}{l}S_{\max } \\
(\%)\end{array}$ \\
\hline & & \multicolumn{2}{|c|}{ Levorphanol } & \multicolumn{2}{|c|}{ Bremazocine } & \multicolumn{2}{|c|}{ DSLET } \\
\hline No treatment & $75 \pm 10.4$ & $9.0 \pm 2.6$ & $24 \pm 4.0$ & $17 \pm 3.5$ & $13 \pm 5.5$ & $6.6 \pm 0.6$ & $25 \pm 5.3$ \\
\hline $\begin{array}{l}\text { A. DIRECT ALKYLAT } \\
\beta \text {-FNA, } 200 \mu \mathrm{M} \\
\text { Superfit, } 100 \mu \mathrm{M} \\
\beta \text {-FNA + Superfit }\end{array}$ & $\begin{array}{l}69 \pm 14 \\
58 \pm 17 \\
68 \pm 9\end{array}$ & $14 \pm 5.5$ & $\begin{array}{l}0 \\
8.7 \\
0\end{array}$ & $\begin{array}{l}6.9 \pm 0.9^{*} \\
12 \pm 4.9 \\
12 \pm 4.4\end{array}$ & $\begin{array}{l}6.5 \pm 1.3^{*} \\
12 \pm 3.6 \\
19 \pm 6.7\end{array}$ & $\begin{array}{c}18 \pm 6.1^{*} \\
-\end{array}$ & $\begin{array}{l}27 \pm 8.3 \\
0 \\
0\end{array}$ \\
\hline$\beta$-FNA + Superfit & & \multicolumn{6}{|c|}{ Dynorphin } \\
\hline
\end{tabular}

B. PROTECTIVE ALKYLATION

\begin{tabular}{|c|c|c|c|c|c|c|c|}
\hline No treatment & (see above) 1 & $\begin{array}{c}\text { Sufen } \\
18\end{array}$ & & $\begin{array}{r}\text { Bremaz } \\
\text { (see ab }\end{array}$ & & $\begin{array}{r}D S L \\
\text { (see a }\end{array}$ & \\
\hline$\beta$-CNA, $25 \mu \mathrm{M}$ & $69 \pm 21$ & - & 0 & - & 0 & - & 0 \\
\hline$\beta$-CNA + sufentanil & $83 \pm 24$ & $5.2 \pm 3.0$ & $22+2.0$ & - & 0 & - & 0 \\
\hline$\beta$-CNA + DSLET & $73 \pm 22$ & - & 0 & - & 0 & $6.0 \pm 0.6$ & $30 \pm 7.0$ \\
\hline
\end{tabular}

For direct alkylation, cerebral membranes of the rat were incubated with $100 \mu \mathrm{M}$ Superfit or $200 \mu \mathrm{M} \beta$-FNA for 40 min at $25^{\circ} \mathrm{C}$ and washed as described under Methods. If treated with both alkylators, incubation with Superfit was followed by washing and treatment with $\beta$-FNA. For protective alkylation, the membranes were incubated with $800 \mu \mathrm{M}$ sufentanil or $400 \mu \mathrm{M}$ DSLET for 5 min at room temperature. Then $\mathrm{NaCl}$ and $\beta-\mathrm{CNA}$ were added to give final concentrations of $100 \mu \mathrm{M}$ and $25 \mu \mathrm{M}$, respectively. After incubation for $40 \mathrm{~min}$ at $25^{\circ} \mathrm{C}$, the membranes were centrifuged and washed as described. The concentration for half-maximal stimulation ( $\left.K_{\mathrm{s}}\right)$, and maximal stimulation $\left(S_{\text {max }}\right.$ ) of the basal activity is shown for the opioid agonists levorphanol and sufentanil (mu), bremazocine and dynorphin-(1-13) (kappa) and DSLET (delta). Shown are mean values and standard deviations obtained in 3-5 experiments carried out in triplicate (the experiment with dynorphin was carried out once). The significance of the data relative to the control values (no treatment) was examined by analysis of variance and a comparison test as described under Methods. The statistically different means are indicated by an asterisk. 


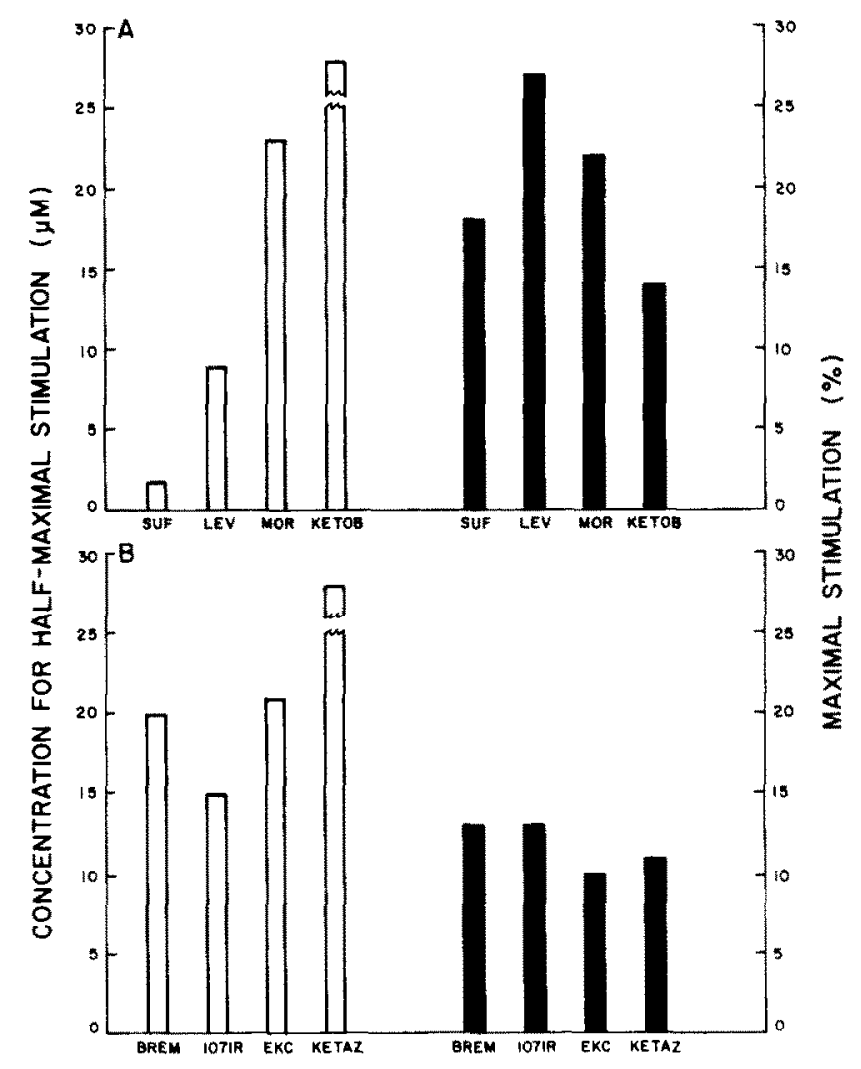

Fig. 1. Stimulation of the activity of GTPase by mu and kappa opiates. The activity of GTPase in cerebral membranes in the presence of various concentrations of a given opiate was measured as described under Methods. Shown are (i) the concentrations of opiates which produced half-maximal stimulation of GTPase ( $K_{\mathrm{S}}$, open bars) and (ii) the maximal stimulation of the basal rate by the opiates $\left(S_{\max }\right.$, closed bars). Represented in (A) are the mu opiates sufentanil (SUF), levorphanol (LEV), morphine (MOR) and ketobemidone (KETOB). The broken bar for KETOB reflects a $K$ s value of $51 \mu \mathrm{M}$. (B) contains results obtained with the kappa opiates bremazocine (BREM), UM 107IR (1071R), ethylketocyclazocine (EKC) and ketazocine (KETAZ). The broken bar for KETAZ reflects a $K \mathrm{~s}$ value of $240 \mu \mathrm{M}$. Shown are the means of data obtained in $3-5$ experiments, each run in triplicate or quadruplicate. Typical standard deviations were $\pm 8 \%$ for $K_{\mathrm{S}}$ and $\pm 6 \%$ for $S_{\max }$. The statistical analysis of the data, carried out as described under Methods, showed that all $S_{\max }$ values in (A) were significantly different from the basal activity of GTPase (mean value $75.2 \pm 10.4 \mathrm{pmol} \mathrm{Pi} / \mathrm{mg}$ protein. $\min$ ). The $S_{\max }$ values in (B) did not meet the $5 \%$ level of significance.

Whereas naloxone blocked the stimulation of GTPase by mu, kappa and delta opiates, the deltaselective opioid antagonist ICI 174,864 specifically inhibited the effect of DSLET (Fig. 2).

In order to resolve the stimulation of GTPase in brain by different types of opioid agonists, siteselective alkylations were carried out. Direct alkylation was accomplished with the mu- and deltaselective irreversible ligands $\beta$-funaltrexamine (Ward, Portoghese and Takemori, 1982) and Superfit (Smith et al., 1985; Clark et al., 1986; Clark and Medzihradsky, 1986). In addition, alkylation with the nonspecific ligand $\beta$-chlornaltrexamine (Ward et al., 1982), in the presence of protective concentrations of selective mu, kappa and delta opiates, respectively, was implemented. The selective opiates included sufentanil and levorphanol as mu, bremazocine as kappa, and DSLET as delta ligands. Initial alkylation with $\beta$-funaltrexamine or Superfit abolished the stimulation of GTPase by mu agonists and delta agonists, respectively (Table 1). In addition, alkylation with both $\beta$-funaltrexamine and Superfit conveyed specificity to the kappa opioid receptor, as demonstrated by the exclusive stimulation of GTPase by kappa opiates. Selective stimulation of GTPase by mu, kappa or delta opiates was also obtained in membranes treated with $\beta$-chlornaltrexamine in the presence of appropriate ligands (Table 1). The concentration of these opiates employed was optimal for protection of receptors, as reflected in the activation of GTPase considering both $K_{\mathrm{s}}$ and $S_{\max }$. Smaller concentrations than those listed resulted in decreased values for $S_{\max }$ and/or increased $K_{s}$, with the latter parameter responding first. As expected, alkylation of membranes with $\beta$-chlornaltrexamine alone abolished stimulation of GTPase by any opiate. 


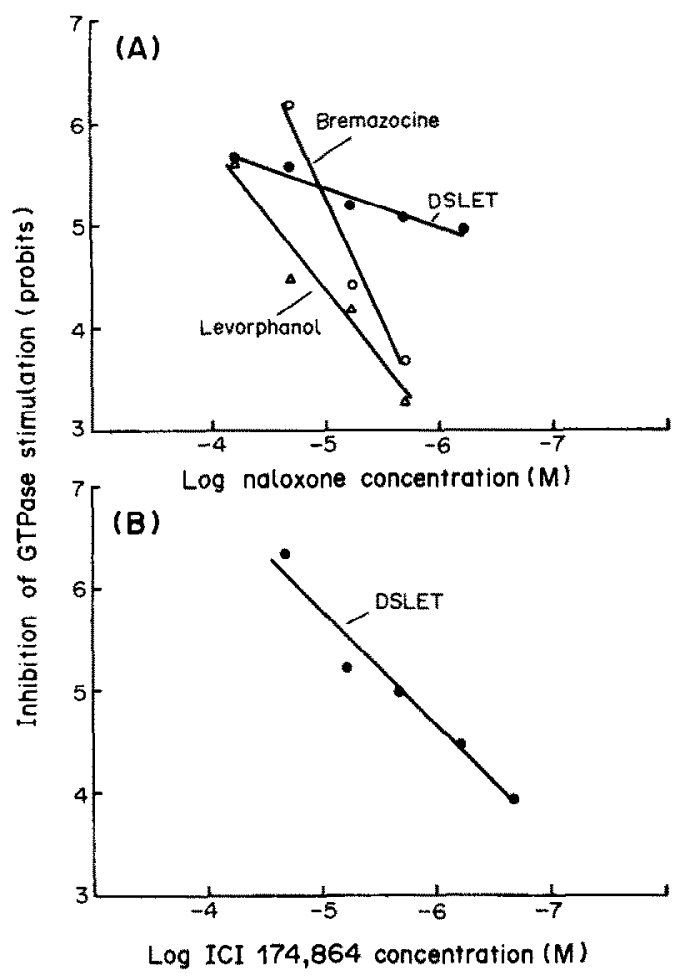

Fig. 2. Inhibition of the stimulation of GTPase by opioid antagonists. The activity of GTPase in untreated cerebral membranes was assayed in the presence of $60 \mu \mathrm{M}$ levorphanol $(\triangle)$, bremazocine $(O)$ or DSLET (O) and different concentrations of naloxone (A) or ICI 174,864 (B). The plots show the probit transformation of percentage inhibition as a function of the concentration of the antagonist. The correlation coefficients $\left(r^{2}\right)$ for the lines were $0.95-0.96$. The $E C_{s 0}$ 's $(\mu \mathrm{M})$ of naloxone in inhibiting the stimulation of GTPase by levorphanol, bremazocine and DSLET were $27 \pm 6,7.6 \pm 1.8$ and $1.1 \pm 0.1$, respectively. The ICI 174,864 inhibited the stimulation of GTPase by DSLET with an $E C_{s 0}$ of $2.0 \pm 0.4 \mu \mathrm{M}$, but did not block the stimulation induced by levorphanol or bremazocine. Shown are mean values of 3 experiments run in triplicate.

Alkylation with gradually increasing concentrations of Superfit, resulted in proportionally decreased stimulation of low-Km GTPase (Fig. 3). Whereas $10 \mu \mathrm{M}$ Superfit had no effect, pretreatment with $100 \mu \mathrm{M}$ of the alkylator abolished the stimulation of enzymatic activity. At all concentrations of Superfit used, the alkylation approximately doubled the corresponding $K_{S}$ value for stimulation of GTPase by DSLET (Fig. 3). Such impairment in the potency of opiates to stimulate GTPase after alkylation was observed in membranes alkylated by the direct approach, but not after protective alkylations using $\beta$-chlornaltrexamine (Table 1).

The coupling of multiple opioid receptors to GTPase in brain was resolved into components by the effect of etorphine, a nonselective opioid agonist, after selective alkylation of receptors (Fig. 4). Stimulation of GTPase induced by the binding of etorphine to the mu and delta receptor was blocked by initial alkylation with $\beta$-funaltrexamine and Superfit, re- spectively. Each of the two alkylations decreased $S_{\max }$ by approximately $10 \%$. The stimulation of GTPase due to occupancy by etorphine of the kappa receptor was determined in membranes alkylated by both $\beta$-funaltrexamine and Superfit, although again the significance of the kappa effect was difficult to establish. Nonetheless, the sum of the individual components of the stimulation of GTPase in response to the occupancy of the mu, kappa and delta receptors equalled in extent the stimulation by etorphine in non-alkylated membranes (Fig. 4).

\section{DISCUSSION}

Based on its characteristics, the stimulation of high affinity GTPase by opiates represents a functional consequence of occupancy of opioid receptors and reflects the interaction of receptors with the inhibitory guanine nucleotide-binding protein (Ni) (Milligan and Klee, 1985). The direct involvement of $\mathrm{Ni}$ in the function of opiates during their acute (Wuster, Costa, Aktories and Jakobs, 1984) and chronic (Lux and Schulz, 1985) presence has been demonstrated. As shown previously, stimulation of GTPase in mammalian brain was stereospecific, limited to opioid agonists and inhibited by antagonists (Barchfeld and Medzihradsky, 1984). Contributing to the relatively large concentrations of opiates at which stimulation of the enzyme occurred (low $\mu \mathrm{M}$ range) was the presence in the assay medium of sodium and GTP which reduced the binding of the agonist to the opioid receptor (Blume, 1978). Accordingly, antagonists exhibited greater potencies in blocking the stimulation of GTPase than did agonists in causing it (Fig. 2). The relatively large effective concentrations of the opiates can also reflect impaired coupling of the opioid receptor to the effector in isolated brain membranes, as compared to intact cellular preparations (Barchfeld et al., 1982; Katz and Catravas, 1977).

In the present work, opiates of all three types stimulated GTPase, although the effect of kappa opiates was of marginal statistical significance. The lesser extent of enzyme stimulation by kappa, relative to mu and delta, ligands corresponds to the low sensitivity of their receptor binding toward the regulation by GTP and Gpp(NH)p (Mack, Lee and Weyhenmeyer, 1985; Clark et al., 1986). Furthermore, the additional coupling of the kappa opioid receptor to an effector system, other than the Niadenylate cyclase complex, e.g. an ion channel (Pfaffinger, Martin, Hunter, Nathanson and Hille, 1985), cannot be ruled out. It has recently been shown that kappa opiates significantly stimulated GTPase in membranes from the cerebellum of the guinea-pig, a tissue predominantly containing kappa opioid receptors (Clark et al., 1986).

Stimulation of GTPase due to ligand occupancy of individual types of opioid receptors was resolved by site-specific alkylations with irreversible ligands. The 

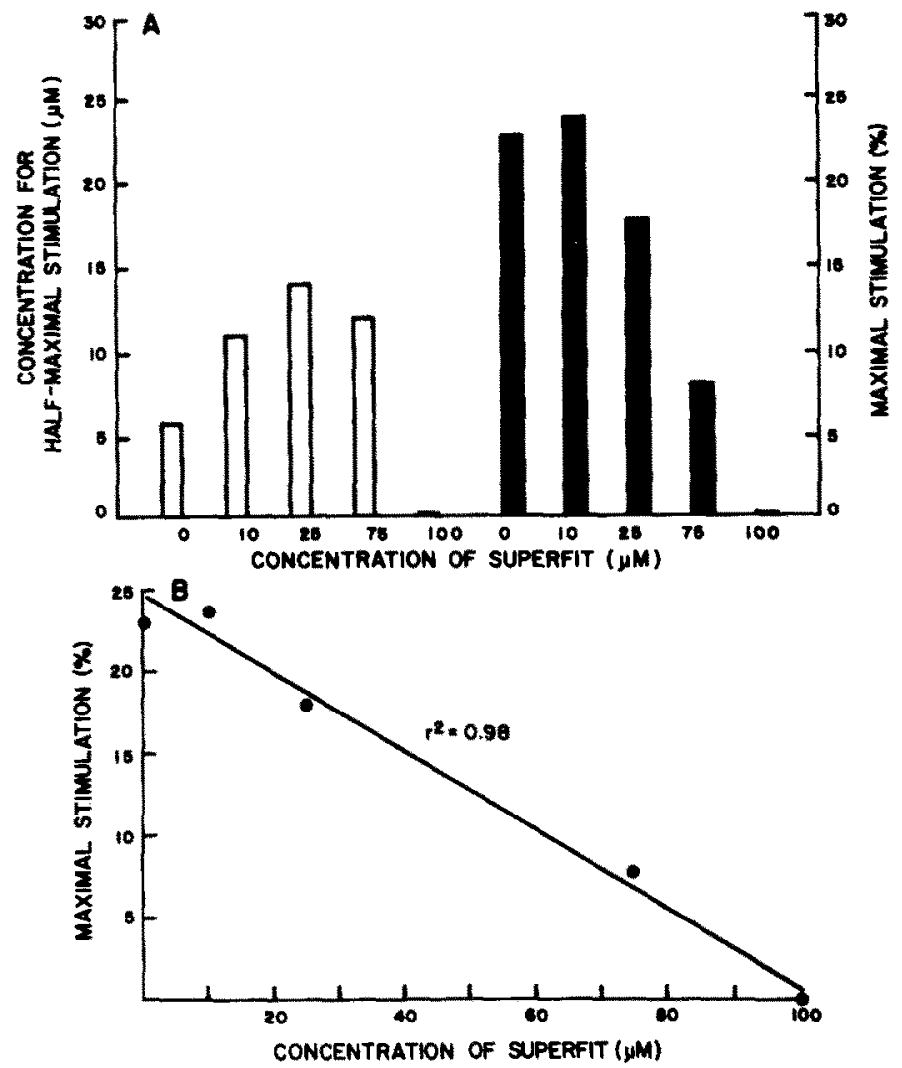

Fig. 3. Effect of partial teceptor alkylation on stimulation of GTPase. Cerebral membranes were treated with the indicated concentrations of Superfit as described under Methods. Control membranes were incubated without the alkylator. Subsequently, the activity of GTPase was assayed: (A) shows the $K_{S}$ values (open bars) and $S_{\max }$ (closed bars). Shown are mean values of 3 experiments carried out in triplicate. The $K_{\mathrm{S}}$ values after treatment with 25,75 and $100 \mu \mathrm{M}$ Superfit were significantly different from those of the unalkylated control (see Methods). The $S_{\max }$ was significantly different from control in membranes treated with 75 and $100 \mu \mathrm{M}$ of Superfit. (B) shows the correlation between stimulation of GTPase and the concentration of Superfit. The correlation coefficient of the line $\left(r^{2}\right)$ was 0.98 , as determined by regression analysis. In membranes treated with $100 \mu \mathrm{M}$ Superfit, DSLET failed to stimulate GTPase.

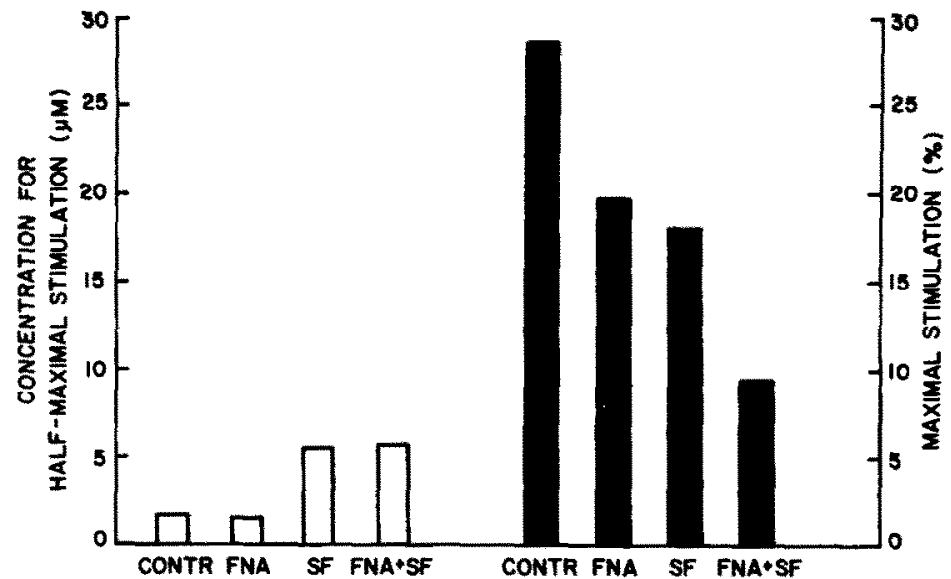

Fig. 4. Multiple components of the stimulation of GTPase by etorphine. Cerebral membranes were treated with either $100 \mu \mathrm{M}$ Superfit (SF) or $200 \mu \mathrm{M} \beta$-funaltrexamine $(\beta$-FNA) or both, as described under Methods. If treated with both alkylators, the membranes were first incubated with Superfit, washed and then treated with $\beta$-FNA. Subsequently, the activity of GTPase was determined: shown are mean values for $K_{\mathrm{s}}$ (open bars) and $S_{\max }$ (closed bars) obtained in 3 experiments carried out in triplicate. Statistical significance (see Methods): mean $K_{\mathrm{s}}$ values differed from control for the SF and SF + FNA treatments; mean $S_{\text {max }}$ values differed from control for the SF + FNA treatment. 
described selectivity of the stimulation of GTPase complements the resolution of ligand binding to multiple opioid receptors, described previously on the basis of selective opiates (Gillan and Kosterlitz, 1982), responses to sodium (Medzihradsky et al., 1984) and site-directed alkylation using $\beta$-chlornaltrexamine (James and Goldstein, 1984). In the present work, both methods of alkylation provided high selectivity to receptor-effector coupling, i.e. abolished the stimulation of GTPase by ligands of the blocked receptors. However, in contrast to the protective approach, direct alkylation generally increased the $K_{\mathrm{S}}$ values of the ligands binding to the receptor to which specificity was conveyed. The increased potency of bremazocine in membranes alkylated with $\beta$-funaltrexamine apparently reflected the elimination of the antagonistic component of this opiate at the mu receptor (Von Voigtlander, Lahti and Ludens, 1983). It is important to note, that the alkylations did not affect the basal rate of the activity of GTPase, and in particular, did not increase it. The approach described here of opioid receptor alkylations yields membranes from brain suitable for the investigation of the selectivity of novel opiates in receptor binding and receptor-effector coupling (Medzihradsky, 1987).

The efficiency of the alkylations was also reflected in the quantitative relationships of receptor-effector coupling: the multiple components of the stimulation of GTPase, resulting from the occupancy by etorphine of the mu, kappa and delta opioid receptor, respectively, were additive and their sum equalled the total enhancement of enzyme activity determined in unalkylated membranes. In addition, the extent of the stimulation of the enzyme was proportional to the degree of alkylation, although the lack of effect on the activity of GTPase after alkylation with $10 \mu \mathrm{M}$ Superfit suggests the presence of spare receptors, as demonstrated recently in cerebral membranes of the rat (Clark and Medzihradsky, 1986). Such a reserve has previously been shown also to exist in the coupling of the opioid receptor to adenylate cyclase in NG108-15 neuroblastoma $\times$ glioma hybrid cells (Law, Hom and Loh, 1983).

The described interactions of multiple opioid receptors with an effector component in the mammalian brain, conveniently determined by its enzymatic activity, provide an additional basis for assessing the consequences of ligand binding to receptor. The present authors have studied the efficacy of opiate binding with the focus on GTP binding proteins (Clark and Medzihradsky, 1986), and are now investigating the relationship between the stimulation of GTPase and the inhibition of adenylate cyclase. On the other hand, the present data do not yet conclusively identify the GTP-binding protein(s) involved in the observed receptor-related stimulation of GTPase. However, the recent availability of specific antibodies to $\mathrm{Ni}$ and $\mathrm{No}$, the latter a pertussis toxin sensitive quanine nucleotide-binding protein present at large concentrations in brain (Gierschik, Milligan, Pines, Goldsmith, Codina, Klee and Spicgel, 1986), should prove useful in resolving their participation in the phenomena described.

Acknowledgements - This work was supported in part by USPHS Grant DA 04087 , and by a grant to F.M. from the Biomedical Research Council at The University of Michigan. The authors are grateful to Dr G. L. Nordby for valuable discussions, and thank Ms Becky McLaughlin for excellent assistance in preparing the manuscript.

\section{REFERENCES}

Barchfeld C. C., Maassen Z. F. and Medzihradsky F. (1982) Receptor-related interactions of opiates with PGEinduced adenylate cyclase in brain. Life Sci. 31: 1661-1665.

Barchfeld C. C. and Medzihradsky F. (1984) Receptormediated stimulation of brain GTPase by opiates in normal and dependent rats. Biochem. Biophys. Res. Commun. 121: 641-648.

Bixby J. L. and Spitzer N. C. (1983) Enkephalin reduces calcium action potentials in Rohen-Beard neurons in vivo. J. Neurosci. 3: 1014-1018.

Blume A. J. (1978) Interaction of ligands with the opiate receptors of brain membranes: regulation by ions and nucleotides. Proc. natn. Acad. Sci. U.S.A. 75: 1713-1717.

Blume A. J., Lichtshtein D. and Boone G. (1979) Coupling of opioid receptors to adenylate cyclase: requirement for $\mathrm{Na}^{+}$and GTP. Proc. natn. Acad. Sci. U.S.A. 76: 5626-5630.

Burns D. L., Hewlett E. L., Moss J. and Vaughan M. (1983) Pertussis toxin inhibits enkephalin stimulation of GTPase of NG108-15 cells. J. biol. Chem. 258: 1435-1438.

Cassel J. and Selinger Z. (1976) Catecholamine-stimulated GTPase activity in tureky erythrocyte membranes. Biochem. biophys. Acta 452: 538-551.

Clark M. J., Levenson S. D. and Medzihradsky F. (1986) Evidence for coupling of the kappa opioid receptor to brain GTPase, Life Sci. 38: 1721-1727.

Clark M. J. and Medzihradsky F. (1985) Heterogeneity in the coupling of opioid receptor to brain GTPase. Proc. Int. Narc. Res. Conf., p. 93. North Falmouth, Massachusetts, U.S.A.

Clark M. J. and Medzihradsky F. (1986) Spare ligand binding sites in the coupling of opioid receptor to brain GTPase. Natn. Inst. Drug Abuse Res. Monogr. U.S.A. 75: $145-148$.

Cotton R., Giles M. B., Miller L., Shaw J. S. and Timms T. (1984) ICI 174864: a highly selective antagonist for the opioid delta receptor. Eur. J. Pharmac. 97: 331-332.

Fischel S. V. and Medzihradsky F. (1981) Scatchard analysis of opiate receptor binding. Molec. Pharmac. 20: 269-279.

Gierschik P., Milligan G., Pines M., Goldsmith P., Codina J., Klee W. and Spiegel A. (1986) Use of specific antibodies to quantitate the guanine nucleotide-binding protein Go in brain. Proc. natn. Acad. Sci. U.S.A. 83: 2258-2262.

Gillan M. G. C. and Kosterlitz H. W. (1982) Spectrum of the mu-, delta- and kappa-binding sites in homogenates of rat brain. Br. J. Pharmac. 77: 461-469.

Hildebrandt J. D., Sekura R. D., Codina J., Iyengar R., Manclark C. R. and Birnbaumer L. (1983) Stimulation and inhibition of adenyl cyclases mediated by distinct regulatory proteins. Nature 302: 706-709.

James I. F. and Goldstein A. (1984) Site-directed alkylation of multiple opioid receptors. I. Binding selectivity. Molec. Pharmac. 25: $343-348$. 
Katz J. B. and Catravas G. N. (1977) Absence of morphine antagonism of prostaglandin $\mathbf{E}_{1}$-stimulated $\left[{ }^{3} \mathrm{H}\right] 3^{\prime}, 5^{\prime}$-cyclic adenosine monophosphate accumulation in a rat brain mince system. Brain Res. 120: 263-268.

Koski G. and Klee W. A. (1981) Opiates inhibit adenylate cyclase by stimulating GTP hydrolysis. Proc. natn. Acad. Sci. U.S.A. 78: 4185-4189.

Kurose H., Katada T., Amano T. and Ui M. (1983) Specific uncoupling by islet-activation protein, pertussis toxin, of negative signal transduction via alphaadrenergic, cholinergic and opiate receptors in neuroblastoma $\times$ glioma hybrid cells. I. biol. Chem. 258: $4870-4875$

Law P. Y., Hom D. S. and Loh H. H. (1983) Opiate regulation of adenosine $3^{\prime}, 5^{\prime}$-cyclic monophosphate level in neuroblastoma $\times$ glioma hybrid cells. Relationship between receptor occupancy and effect. Molec. Pharmac. 23: 26-35.

Law P. Y., Wu J., Koehler J. E. and Loh H. H. (1981) Demonstration and characterization of opiate inhibition of the striatal adenylate cyclase. $J$. Neurochem. 36: $1834-1846$.

Lowry O. H., Rosebrough N. A., Farr A. L. and Randall R. J. (1951) Protein measurement with the Folin phenol reagent. J. biol. Chem. 193: 265-275.

Lux B. and Schulz R. (1985) Opioid dependence prevents the action of pertussis toxin in the guinea-pig myenteric plexus. Naunyn-Schmiedebergs Arch. Pharmac. 330: 184186.

Mack K. J., Lee M. F. and Weyhenmeyer J. A. (1985) Effects of guanyl nucleotides and ions on kappa oploid binding. Brain Res. Bull. 14: 301-306.

Medzihradsky F. (1987) Novel biochemical correlates in the preclinical evaluation of opiates. Natn. Inst. Drug Abuse Res. Monogr. U.S.A. 76: 349-355.
Medzihradsky F., Dahlstrom P. J., Woods J. H., Fischel S. V. and Mitsos S. E. (1984) Resolution in the receptor binding of putative mu and kappa opiates. Life Sci. 34: 21292138 .

Milligan $G$, and Klee W. A. (1985) The inhibitory guanine nucleotide-binding protein (Ni) purified from bovine brain is a high affinity GTPase, $f$. biot. Chem. 260: 2057-2063.

Pfaffinger P. J., Martin J. M., Hunter D. D., Nathanson N. M. and Hille B. (1985) GTP-binding proteins couple cardiac muscarinic receptors to a $\mathbf{K}$ channel. Nature 317: $536-538$.

Scheffe H. (1953) A method for judging all contrasts in the analysis of variance. Biometrika $40: 87-104$.

Sharma S. D., Nirenberg M. and Klee W. A. (1975) Morphine receptors are regulators of adenylate cyclase activity. Proc. natn. Acad. Sci. U.S.A. 72: 590-594.

Smith C. B., Jacobson A. E., Burke T. R., Rice K. C. and Woods J. H. (1985) Actions of "irreversible" delta opiate receptor agonists on the mouse vas deferens. Fed. Proc. 44: 610.

Von Voigtlander P. F., Lahti R. A. and Ludens J. H. (1983) U-50,488: a selective and structurally novel non-mu (kappa) opioid agonist. J. Pharmac. exp. Ther. 224: 7-12.

Ward S. J., Portoghese P. S. and Takemori A. E. (1982) Phamacological profiles of $\beta$-funaltrexamine $(\beta-\mathrm{FNA})$ and $\beta$-chlornaltrexamine $(\beta-\mathrm{CNA})$ on the mouse vas deferens preparation. Eur. J. Pharmac. 80: 377-384.

Williams J. T. and North R. A. (1984) Opiate-receptor interactions on single locus coeruleus neurons. Molec. Pharmac. 26: $489-497$.

Wuster M., Costa T., Aktories K. and Jakobs K. H. (1984) Sodium regulation of opioid agonist binding is potentiated by pertussis toxin. Biochem. biophys. Res. Commut. 123: $1107-1115$. 